\title{
Reading between the Lines: \\ Party Cues and SNP Support for Scottish Independence and Brexit
}

\begin{abstract}
Scotland's future within the EU played a prominent role in the 2014 independence referendum. The story goes that latent supporters of independence voted to stay within the UK to maintain EU access. Defeated, Scottish leaders declared the referendum a once-in-alife-time event only repeated if conditions substantially changed. With the UK now facing a chaotic exit from the EU, proponents of Scottish independence have suggested that a second referendum may occur after Brexit negotiations are completed. Faced with a consensus among Scottish party leaders in supporting EU membership, those hoping for a second independence referendum, we argue, looked to alternate sources of information that saw Brexit as an opportunity to create the conditions that would spur a second referendum. Using panel data from the British Election Study, we examine whether Scottish voters voted tactically to leave the EU. We argue that SNP voters were likely to interpret statements on the conditions for a second independence referendum as an implicit signal to vote "Leave". The results have important implications for the role of referendums in representative democracy, strategic voting, and the importance of intra-party division on individual vote choices.
\end{abstract}

Key words: Strategic Voting, Referendums, EU, Brexit, Scottish Independence, Intra-Party Disagreement 


\section{Introduction}

Days after the surprise win for the UK campaign to leave the European Union (EU), prominent Scottish nationalists began calls for a second Scottish independence referendum. Public opinion mirrored these appeals as support for independence surged to new highs (up to $59 \%$ in one survey). ${ }^{1}$ This response may be unsurprising as all parties represented in the Scottish Parliament converged on a similar position and campaigned to remain in the EU. Citizens voted overwhelmingly to stay (62\%). Yet, the story is more complex. Despite broad convergence of party elites on support for remaining in the EU, the parties' stated positions masked internal divisions over policy goals and strategy. For example, Nicola Sturgeon, leader of the Scottish National Party (SNP), expressed strong support to remain in the EU, expounding on its numerous benefits for Scotland. Prominent nationalists, such as former SNP leader Gordon Wilson, indicated support for an alternate approach; vote to leave the EU to create the conditions for a new independence referendum (Green 2016). ${ }^{2}$ Further, in a televised debate, former SNP leader Alex Salmond projected that if the UK votes to leave the EU, a second Scottish independence referendum will occur within two years. Salmond's comment led Willie Rennie, leader of the Scottish Liberal Democrat Party, to comment that this could encourage SNP supporters to vote in favour of the UK leaving the EU (Johnson 2016). Even Sturgeon's statements on the EU referendum suggested competing motives; she had previously linked leaving the EU as grounds for a future independence referendum.

Faced with competing messages from prominent elites within parties that introduced opposing policy goals, supporters of an independent Scotland faced a choice between a sincere vote to stay in the EU, and an instrumental vote for an uncertain independence referendum. High levels of aggregate support for the "Remain" camp may have masked the prevalence of instrumental voting. ${ }^{3}$ Indeed, areas such as Glasgow that voted in favour of

\footnotetext{
1 See Curtice's (2016) discussion of the strengths and weaknesses of these polls. This discussion implies that the real increase was smaller, but did increase to majority support for Scottish independence.

2 Importantly, Gordon Wilson's remarks were repudiated by others in the SNP (see Green 2016), adding to the mixed cues sent by prominent party leaders. We thank a reviewer for drawing our attention to these reactions.

${ }^{3}$ We use a number of phrases particular to the campaigns. "Remain" and "Leave" refer to the official electoral campaigns in support of remaining within the EU or leaving the EU since these were the slogans and names endorsed by the campaigns. We also use these terms to refer to the vote itself. We refer to the United Kingdom leaving the EU as "Brexit" as politicians and the media often refer to the process.
} 
Scottish independence in 2014 faced lower turnout than more Unionist cities (despite Unionists actually being more likely to support the leave campaign in pre-referendum polls). ${ }^{4}$ Strategic voting, thus, may be more prevalent than the aggregate indicators alone predict.

We argue that many in favour of an independent Scotland demonstrated support for independence by voting to leave the EU. Further, we posit, based on the logic of strategic voting and elite signalling, that in the face of competing messages from non-partisan elites, those in support of Scottish independence, who also supported the SNP, chose to go against the party's dominant message and voted to leave the EU. For these voters, the parallel argument on the conditions required for a second independence referendum acted as an implicit cue to reinterpret the leadership's more explicit statements in support of remaining in the EU.

We test the argument using panel data from the third and eighth waves of the British Election Study in Scotland. In particular, we connect respondents' support for independence in the 2014 referendum to their self-reported behaviour in the 2016 EU referendum. We find that supporters of Scottish independence were more likely to vote in favour of the UK remaining in the EU; however, they were also more likely to pursue alternate voting strategies, depending on their identification with the SNP.

The theory and results have important implications for the role of referendums in representative democracy. From a theoretical standpoint, this study suggests that voters do not approach referendums in a vacuum. Rather, referendum vote choices may be influenced by choices in previous or expected future referendums. Further, this study addresses the role that strategic voting can play, and the role party politics, specifically intra-party division, has in influencing vote choices. Although public discourse often celebrates referendums as a more "pure" form of democracy, the exact question asked, as well as other political conditions, may create opportunities for tactical considerations. The expectation of future referendums on alternate, but connected, policy choices shifts voters' calculus from the simple binary decision expected by many advocates of direct democracy to a more complicated multi-dimensional problem. By considering the multi-dimensional

4 For example, the district encompassing Glasgow city centre achieved a voter turnout of approximately $56.3 \%$ in the EU referendum in contrast with $73 \%$ turnout in the Edinburgh city centre district (The Electoral Commission, 2016). 
consequences of their vote choice, this perspective creates the opportunity for tactical voting in referendums. Forward looking, tactical voters may vote to set the future agenda, rather than express their sincere preferences on future participation within the EU, which in this specific case may be a second referendum on Scottish independence. These results suggest that popularly elected leaders should think twice before using referendums to avoid or meet political aims on important issues, as the effect of elite cues may be limited.

\section{Referendums and Voting Behaviour}

Studies suggest that voters act in similar ways in referendums as they do in other contexts. A growing area of research considers the relationship between referendums and election campaigns (see, for example, Uleri and Gallagher 2016). Although referendums are a distinct subset of elections, studies find that demographic and attitudinal considerations influence voters in referendums similar to their impact in decision-making processes in other contexts. For example, national identity matters in votes on devolution and EU referendums in a range of settings such as Wales (Jones and Scully 2012), the Czech Republic (Hanley 2007), and the Baltic States (Mikkel and Pridham 2004).

Not all studies of direct democracy focus solely on demographic, attitudinal, economic or structural indicators, however. Past research on referendums in the EU, for example, shows that support for the outcome depends on the popularity of the sitting governmental parties (Franklin et al. 1995). Markowski and Tucker (2005) illustrate evidence of individual level strategic behaviour in Poland. They find that many opposed to joining the EU sought to invalidate the 2003 referendum by not turning out to vote. In particular, voters tried to deny the $50 \%$ mandatory threshold rather than turnout out to vote against joining the EU.

Citizen information about referendums likely also matters. De Vreese and Semetko (2004), for example, show that the media played a role in the 2000 EU referendum in Denmark. Citizens' vote choice responded to exposure to public television campaign advertisements. In a number of EU referendums, Hobolt (2005), moreover, finds that more informed voters rely less on elite cues. In the Irish case, Marsh (2015) finds evidence that party cues, incumbency and issues play an important role in vote choice. 
Although referendums seem to offer relatively simple, distinct alternatives at face value, voters' decision-making calculi may be more complex. Referendums can disrupt or limit the usefulness of the normal set of cues and heuristics voters us to make informed decisions (see also Quinlan 2012). In the Scottish referendum, for example, the SNP acted as the primary advocate of an independent Scotland, whereas the other major parties largely advocated remaining in the UK. Conversely, the EU referendum placed all major parties in Scotland on the same footing according to their official positions, advocating to remain in the EU. This policy convergence created a context that amplified the role played by intraparty dissent among current and former party elites. While no Scottish party leaders advocated the Leave position, the lack of policy disagreement among the major parties likely created an opportunity for a wider (and potentially less traditional) range of voices. Indeed, Scottish voters may have perceived goals for independence and a vote to remain in the EU at odds. Whereas voters in England and Wales likely voted Leave for sincere policy reasons; voters in Scotland might have voted Leave for tactical reasons.

\section{Voter Coordination and Tactical Voting}

Electoral rules induce strategic voting behaviour. Under single member districts in a unidimensional setting, for example, voters may select a candidate other than their most preferred, but who has a higher chance of winning the election to reduce the chance that an even less preferred candidate wins (Downs 1957). Tactical voting occurs in a range of systems, including those with open and closed list proportional representation and mixed member rules (e.g. Gschwend 2007).

In the context of a referendum, a tactical vote would entail a choice to support the less preferred outcome because the voter hopes that her vote will lead to a new status quo supporting a third potential outcome. From the perspective of a tactical voter, a vote to leave the EU, might have created the dissatisfaction within Scotland (where hypothetically over $60 \%$ of voters supported independence because of their desire to remain in the EU) to hold a 
new, more successful referendum. ${ }^{5}$ Although this perspective requires a number of assumptions of what would happen following a Leave vote, past referendums on the EU suggest that voters acted tactically or instrumentally in these settings (Markowski and Tucker 2005).

Importantly, voters supporting Scottish independence would not have had to develop this logic on their own. Although far from the official position of the party, prominent members of the SNP, such as Nicola Sturgeon, suggested that a "material change" such as a vote to leave the EU may lead to a second independence referendum. In fact, former Scottish First Minister Alex Salmond, stated, unequivocally, in a nationally televised debate regarding Brexit, that a vote to leave the UK could lead to a second Scottish independence referendum within two years (Johnson 2016). Some media, moreover, discussed the merits of a tactical vote in the run up to the referendum (e.g. Green 2016). Voters who prioritized Scottish independence had the signals and logic presented to them. Indeed, as evidence from the Irish case suggests (e.g. Quinlan 2012), the cross-party agreement on support for EU membership likely further encouraged voters to consider other cues in their voting decision. A vote for Leave could be construed as support for a second Scottish independence referendum. Following this logic, those who voted for Scottish independence in 2014 would likely be those who would prefer a second independence referendum. Therefore, we would expect that these individuals would be more likely to vote in favour of Brexit to shift the status quo and spur a new Scottish independence referendum, which is our first hypothesis.

H1: Voters who supported Scottish independence are more likely to vote to leave the EU.

\section{Partisan Identification and Mixed Signals}

Strategic behaviour requires that voters not only hold information about current vote choices and how fellow citizens will likely act, but also about the implications of that choice (Meffert and Gschwend 2010). Lago (2008), for example, shows that citizens in Spain use past election results as a heuristic to predict future coalition participation. Voters might also

\footnotetext{
${ }^{5}$ Public support for a second independence referendum soared in the weeks following the EU vote (see Curtice 2016). The initial bump was, however, short lived. An August poll carried out by YouGov found support for a second referendum declined to $46 \%$ (https://yougov.co.uk/news/2016/09/01/).
} 
use parties' participation in coalitions to infer information about the parties' positions (Fortunato and Stevenson 2013; Spoon and Klüver 2017). Past electoral behaviour is less useful in referendums, however, as levels of information available to voters depend on the salience and intensity of campaigns (Hobolt 2005).

Theories of democracy propose that parties serve as a linkage between voters and government (Lawson 1980, 2005; Dalton et al. 2011). One major function of parties is to mobilize voters and to serve as a heuristic or cue on the ballot when it comes time to vote (Dalton and Wattenberg 2000). Parties can, moreover, be thought of as brands, each with a distinct "product" to offer (Downs 1957; Aldrich 1995; Cox 1997; Lupu 2013). By providing voters with a heuristic or cue to follow, parties can reduce the cost or burden of voting to the individual. In many cases, parties also provide direct information about how to vote tactically under specific electoral rules (Gschwend 2007).

The mechanism that leads voters to deviate from their party's official message emerges from party policy convergence, intra-party dissent, and conflicting priorities. Despite convergence, parties' statements can still inform voters about how they should vote. Indeed, a substantial body of research emphasizes partisanship and party campaigns as tools for elite messaging and as a form of voter heuristic. Research specific to referendums suggests that elite messages are integral in influencing vote choices (Darcy and Laver 1990; Siune et al. 1994; Quinlan 2012). For example, Darcy and Laver (1990) find that the campaign opposed to the passage of a constitutional amendment to allow for divorce in a 1986 Irish referendum created doubts in the minds of voters, and led to an unexpected vote against the measure. Additionally, Siune et al. (1994) and Quinlan (2012) show that elite campaigns had a significant impact on voters' choices in the 1993 Danish referendum on the Maastricht Treaty, and the 2008 Irish referendum on the Lisbon Treaty. ${ }^{6}$

Literature on parties' election campaigns provides some insights into the role of elite messages on voter behavior. From the perspective of an electorally motivated leader, a party would position itself to maximize its potential votes (Adams 1999; Spoon 2011) which would be broad enough to allow voters to project their own goals on the party (Shepsle 1972; Somer-Topcu 2015), and would emphasize the issues that encourage an image of

\footnotetext{
${ }^{6}$ Importantly, Quinlan (2012) does not focus on the role of parties. His findings that the campaign matters in determining vote choice in referendums, however, suggests that in those countries in which parties do become involved in the campaign, their messages will matter.
} 
competence (Petrocik 1996; Green and Jennings 2011a; Hobolt and de Vries 2012; Greene 2015). Importantly, these strategies require a somewhat unrealistic assumption that party leaders, MPs and members express a consistent message.

Contrary to this assumption, groups within parties hold and often express diverse preferences. Ceron (2012; 2013; 2014), for example, shows that intra-party factions in Italian parties diverge in non-election years, although they converge on the leader's position prior to an election. The distribution of preferences within French and German parties, moreover, increases when they are in government and the party expects to be punished by voters for the economy (Greene and Haber 2014). Parties with parliamentary delegations from diverse backgrounds write more diversified platforms (Greene and O'Brien 2016) and their MPs address a greater range of issues in parliament (Bäck et al. 2014). Evidence of disagreement within Scottish parties, therefore, is not unique. Party leaders, MPs and members hold a distribution of preferences over a diversity of issues and dimensions.

Further, parties' messages are often the result of intra-party decision-making and compromise. Spoon and Williams (2017), for example, find that intra-party division conditions parties' responsiveness to public Euroskepticism. Parties' manifestos, moreover, likely respond to shifts in voter preferences when party leaders are less constrained by their activists (Schumacher et al. 2013). Public perceptions of intra-party division hold real consequences for parties, as voters consider them less competent and are less likely to vote for them (e.g. Greene and Haber 2015).

Despite mixed messages from parties and elites, evidence suggests that voters use symbols such as partisan identification to make decisions about politics. Informational shortcuts such as partisan labels can be useful in a range of settings (Lupia 1994; Lupia and McCubbins 1998). Yet, voters may rely on overly broad heuristics in complex informational environments (Lau and Redlawsk 2001). Parties divided on an issue, and signalling mixed messages, likely complicate the use of overly simple heuristics. Voters may hear competing messages: the official (explicit) message of the party and a more subtle, even hidden (implicit) message from party elites. ${ }^{7}$ Evidence suggests that in the case of mixed or

\footnotetext{
7 This outcome is different than when the party system is highly divided or polarized. Levendusky (2010), for example, has shown that when elites are more polarized, cues from the party can be clearer. Voters are better able to identify the parties' positions and their policy views are more consistent with their issue preferences.
} 
conflicting signals, their effectiveness decreases. Indeed, in the case of relatively basic cues such as partisanship and gender, voters are more likely to hold incorrect beliefs about their party's positions when they conflict (Pyeatt and Yanus 2016).

In addition, when parties present a divided or disunited message, research suggests that parties' cues compete with other signals as their message is weakened. Voters are less likely to perceive parties as competent on issues or vote for those parties when they also perceive them as divided (Greene and Haber 2015). Factors such as the economy greatly influence voters' perceptions of the parties themselves (Green and Jennings 2011a, 2011b). Moreover, voters likely interpret parties' signals through an ideological lens. They are more likely to perceive parties in a positive light and are more likely to respond to parties' campaigns when they are ideologically close (van der Brug 2004; Bélanger and Meguid 2008; Vegetti 2014). Thus, when voters are faced with competing messages over how to achieve distinct policies on issues they are likely to agree with, and act on, the signals that most readily correspond with their position on the most important of these policy dimensions are the ones they will likely follow.

This discussion has implications for the Brexit vote. Elite messages and campaigns can influence voters' choices in referendums (Darcy and Laver 1990; Siune et al. 1994; Quinlan 2012). Despite the major parties' official positions supporting Remain, the EU referendum presented voters with the opportunity to question and subsequently deviate from the official positions (see Darcy and Laver (1990) for a discussion of the effects of a lack of a clear elite message on referendum voting decision). Messages from prominent supporters of the SNP acted as a distinct signal from some SNP elites that a vote in favour of Brexit could lead to a second Scottish independence vote, and provided a strong impetus for SNP supporters to vote in favour of Brexit. This effect was particularly strong among those who were most in favour of a second Scottish independence referendum. Indeed, those in support of an independent Scotland could easily reinterpret statements of support to Remain in the EU as the responsible and necessary positions for the party in government, while simultaneously justifying their decision to vote Leave with the SNP's threats directed towards Westminster of a second referendum outcome if the UK voted to leave the EU. Faced with competing signals, this was likely a challenging decision to these voters, as their immediate goals conflicted with an uncertain potential to meet their more important long- 
term goals. The difficulty of this choice along with the reduced usefulness of party labels likely limited the scope of this outcome while also incentivizing tactical behaviour. Following this logic, we expect that supporters of the SNP, who also favour a second Scottish independence referendum, would be more inclined to tactically vote in favour of Brexit in the hopes of altering the status quo to spur a second Scottish independence referendum. While in our first hypothesis, we perhaps have an overly simple expectation that all supporters of Scottish Independence voted tactically, in our second hypothesis, we narrow the scope of the prediction to those most likely to perceive competing messages from party leaders: SNP supporters.

H2: Voters who supported Scottish independence and identify with the SNP are more likely to vote to leave the EU.

In summary, we hypothesize that supporters of Scottish independence voted instrumentally in the EU referendum, voting in favour of Brexit in order to change the status quo and bring about a second Scottish independence referendum. Further, we posit that, because of division among the official SNP position regarding Brexit and the signals some SNP elites sent regarding the possibility of a second Scottish independence referendum if Leave won, this effect should be particularly strong among those who favour Scottish independence and support the SNP.

\section{Data and Methods}

To test the above hypotheses, we use panel data from the British Election Study (BES) Internet Panel, focusing only on those respondents who had the right to vote in the 2014 Scottish Independence Referendum. The data used in this study comes from either Wave 3, which was conducted immediately following the Scottish independence referendum in September 2014, and Wave 8, which was conducted immediately preceding 
the Brexit vote in 2016. The BES panel study has the benefit of covering the same individuals' vote choices for the Scottish independence and the EU referendums. ${ }^{8}$

We use voters' self-reported intention to vote in favour of the United Kingdom leaving the EU in June of 2016 as the dependent variable. To operationalize this variable, we rely on the BES Panel Study Wave 8 question, “If there was a referendum on Britain's membership of the European Union, how do you think you would vote." We coded those who responded that they would vote to "Leave the EU" as 1, while those who responded that they would vote to "Stay in the EU" were coded 0 . We exclude from the analysis those who reported that they would not vote, or did not know. This results in a mean value of 0.37 and a standard deviation of 0.48 for the full sample of Scottish respondents. ${ }^{9}$

The main independent variable used in testing $\mathrm{H} 1$ is a dichotomous variable indicating whether an individual voted for or against Scottish independence in the 2014 referendum. We operationalize this variable using BES Panel Study Wave 3 data based on the question, "And how did you vote in the independence referendum?" Individuals were coded as a 1 if they voted for Scottish independence, and 0 if they voted against Scottish independence. We omit those who did not vote in the Scottish independence referendum or did not know how they voted referendum. This variable has a mean of 0.47 , with a standard deviation of 0.50 in the full sample. ${ }^{10}$

To test $\mathrm{H} 2$, we create an interaction between a respondent's vote choice in the Scottish independence referendum and whether an individual identifies with the SNP. Support for the SNP was operationalized as a dummy variable based on the BES Wave 8 question, "Generally speaking, do you think of yourself as Labour, Conservative, Liberal Democrat, or what?" Those who answered this question with a response of SNP were coded with a value of 1 . All others were coded as 0 . This variable has a mean of 0.14 with a

\footnotetext{
8 The internet panel was implemented as an online survey by YouGov from February 2014 to December 2016. For additional information about the survey, see the Appendix or Fieldhouse et al. (2016).

${ }^{9}$ In the BES Scottish sample, 63\% supported Remain; whereas, $62 \%$ of Scottish voters actually voted to Remain on June 23, 2016 indicating that the Wave 8 data provides a fairly representative measure of Brexit referendum vote choice.

${ }^{10}$ We used Wave 3 data as respondents were more likely to remember exactly how they voted in the Scottish independence referendum when asked soon after casting a ballot rather than years later. In the sample, $47 \%$ of Scots recalled voting for independence, whereas $45 \%$ of Scots voted for independence on September 18, 2014. This suggests that the Wave 3 data provides a fairly representative measure of Scottish independence referendum vote choice.
} 
standard deviation of 0.34 . The interaction variable (vote for Scottish independence*identification with the SNP) ranges from 0 to 1 , with a mean of 0.15 and a standard deviation of 0.36 .

We also include a number of control variables. First, we include traditional vote choice indicators as control variables: age cohort, education, gender, marital status, and personal income. ${ }^{11}$ Second, we also incorporate variables measuring EU efficacy and EU political knowledge. Our EU efficacy variable is based on the BES Panel Wave 8 question, "How much do you agree or disagree with the following statements? I have a pretty good understanding of the important issues at stake in the EU referendum." Respondents were able to choose from one of 5 responses, "Strongly disagree," "Disagree," "Neither agree nor disagree," “Agree," or "Strongly agree." Those who answered "Don't Know" were excluded from the analysis. The variable has a mean of 3.77 and a standard deviation of 0.89 in the full sample. Our EU political knowledge variable is an additive variable derived from a battery of six (6) "true or false" questions about the EU in the BES Panel Wave 8. The variable has a mean of 1.42 , with a standard deviation of 1.91 in the full sample. ${ }^{12}$ Our final control variable focuses on respondents' perceptions of the clarity of the campaign material they received during the EU referendum campaign. We create a logged scale of campaign clarity from the two measures of campaign information included in Wave 8 of the BES panel. This variable equals the natural log of the difference between the amount of campaign information respondents report having received from the Leave and Remain campaigns. ${ }^{13}$ This measure

\footnotetext{
${ }^{11}$ See the Appendix for the questions used to measure these variables.

${ }^{12}$ Respondents were asked to answer true or false to the following statements, "Each EU Member State elects the same number of representatives to the European Parliament;" "Switzerland is a member of the EU;" "Croatia is a member of the EU;" "The EU spends more on agriculture than any other policy area;" "The European Court of Human Rights only has jurisdiction over EU members;" "The European Union is made up of 15 member states." If a respondent answered a question correctly s/he was given 1 point for a maximum of 6 possible points.

${ }^{13}$ The scale is based on the difference between responses to the two campaign information variables on the question "To what extent do you agree or disagree with the following statements?" "The leave campaign has provided clear information about why we would be better off leaving the European Union." "The remain campaign has provided clear information about why we would be better off remaining in the European Union." Respondents choose between a 5 point scale ranging from "Strongly Disagree" to "Strongly Agree". To estimate the scale we divide each of the campaign items by 5 so that they range from 0 to 1 and then subtract the values. We then calculated the natural $\log$ of the items (plus 1).
}

$$
\text { ClarityScale }=\ln \left(1+\frac{\text { LeaveClarity }}{5}-\frac{\text { RemainClarity }}{5}\right)
$$


allows us to control for the relative clarity of information provided by the campaigns in a single measure. Higher values indicate that the respondent perceived the Leave campaign as having a clearer campaign than the Remain campaign. On average, respondents reported the Remain campaign as slightly clearer with a mean value of -0.04 and a standard deviation of 0.26 in the full sample. For descriptive statistics, see Table A.1 in the Appendix.

As our dependent variable is dichotomous, we use logistic regression (Long 1997). Additionally, we use robust standard errors to estimate our models.

\section{Analysis}

Our first hypothesis (H1) predicts that those who voted in favour of Scottish independence in 2014 were more inclined than those who voted against independence to vote in favour of Brexit. Model 1 presents the results of a logistic regression testing this hypothesis. In contrast to our expectation, an individual's vote in the 2014 Scottish independence referendum is statistically significant and negative. This indicates that if an individual voted in favour of Scottish independence in 2014, she was more inclined to vote in favour of the United Kingdom remaining in the EU.

\section{[INSERT TABLE 1 ABOUT HERE]}

We show the predicted differences in the likelihood of voting to Leave in Figure 1. As the coefficient indicates, the likelihood of voting for Brexit is actually lower for those respondents who reported voting for Scottish independence. Those supporting Scottish independence have a lower probability of voting Leave of approximately 0.05 in comparison to those not voting for independence. ${ }^{14}$ In the face of broad party consensus, it appears that the average supporter for independence was actually more likely to use party cues to support remaining in the EU (e.g. Lupia 1994; McCubbins and Lupia 1998; Quinlan 2012).

\section{[INSERT FIGURE 1 ABOUT HERE]}

\footnotetext{
${ }^{14}$ Despite the overlap in the confidence intervals in the predicted likelihoods presented in Figure 1, the effect is statistically different at the $95 \%$ level in Model 1.
} 
Model 2 adds a dichotomous variable indicating whether an individual supports the SNP. When the SNP variable is included, the effect of the Scottish independence vote variable remains negative, but becomes statistically insignificant. Additionally, the SNP dummy variable is negative but also statistically insignificant. This suggests that the main finding of Model 1, that a vote for Scottish independence in 2014 is associated with a vote for the $\mathrm{UK}$ to remain in the EU, is not robust. It further suggests that identifying with the SNP has important effects that may condition the effect of voting for Scottish independence.

Model 3 presents the results of a test of H2 that SNP supporters who voted for Scottish independence were more likely to vote in favour of the United Kingdom leaving the EU. The interaction between a respondent's identification with the SNP and her vote in the Scottish independence referendum, is positive (the expected direction) and statistically significant. This indicates that those who identify with the SNP and who voted for Scottish independence were more likely to vote for the UK to leave the EU. ${ }^{15}$

To explore the substantive impact of voting for independence on an individual's vote choice in the Brexit referendum when she identifies with the SNP, we computed a predicted effects plot based on Model 3 (holding independent variables at mean or median values for dichotomous variables). As in Figure 1, the y-axis of Figure 2 shows the predicted likelihood of voting for the UK to leave the EU, the $\mathrm{x}$-axis indicates whether an individual voted for Scottish independence or not. Those who support the SNP and voted against Scottish independence have a likelihood of voting for Brexit of roughly 0.075. At the same time, those SNP supporters who voted for Scottish independence have a likelihood of voting for Brexit of about 0.20. That is to say, among SNP supporters, those who voted for Scottish independence were nearly three times as likely to vote for Brexit as those who voted against Scottish independence on average. These results are consistent with a story in which at least some voters with a strong preference on a second dimension of conflict seek alternative signals in the case of elite preference convergence (Darcy and Laver 1990; Siune et al. 1994; Quinlan 2012).

15 In Tables A.2 and A.3 in the Appendix, we replicate Model 1 by the respondent's party identification (Table A.2) and Model 3 by interacting a respondent's party identification with voting for Scottish independence. Although the main English parties were divided, our results suggest their Scottish counterparts were not as overtly divided on the question of whether to leave the EU. 


\section{[INSERT FIGURE 2 ABOUT HERE]}

Several of our control variables also confirm our expectations and reach standard levels of statistical significance. We find that age, education level, and perceived campaign clarity, to be statistically significant in all three models. The coefficient for age is positive, indicating that older voters were more likely to vote in favour of the UK leaving the EU. Education, conversely, has a negative relationship with voting for Brexit; those with more education were less likely to vote in favour of the UK leaving the EU. The coefficient for the campaign clarity scale is positive; those who saw the Leave campaign as having a clearer message were more inclined to vote in favour of the UK leaving the EU, and vice versa. Since the average perception of campaign clarity is negative, this suggests that the Remain camp actually benefited in aggregate from their campaign information. Additionally, efficacy was statistically significant and positive in both Models 1 and 2, suggesting that those who felt that they had a better grasp of the issues at stake in the Brexit referendum were more likely to vote in favour of leaving the EU.

\section{Conclusion}

In this article, we have sought to understand the role of tactical voting in referendums by exploring the relationship between the Scottish independence and Brexit referendums. We hypothesized that voters use elite signals (even in a context of elite preference convergence) to negotiate a tricky choice: support the short-term goal (remain in the EU) or vote for a less desired outcome (leave the EU) with the intention of setting up the conditions for a second referendum on Scottish Independence. By linking the outcome of one referendum to the potential for a future vote, a simple unidimensional question was turned into a multidimensional problem. Signals such as the prominent statement from the Scottish First Minister made clear that a new independence referendum would only occur following a "material change" in support for Scottish independence. ${ }^{16}$ This, in turn, created

\footnotetext{
${ }^{16}$ Given the prominence of the EU in the Scottish independence referendum, those in support of independence easily could have believed that Brexit would bring about these conditions. Sturgeon commented on the need for a "material change" during a debate between Scottish party leaders held on April 6 by STV in the run up to the 2016 Holyrood elections (BBC, April 8, 2016). This statement
} 
the opportunity for a tactical vote. Following this logic, we posited that those who favour Scottish independence from the United Kingdom would vote tactically by voting to Leave the EU. We further argued that this effect would be particularly strong among those who favour Scottish independence and support the SNP, as they received mixed messages from the party's official position and former party elites. Ultimately, the SNP's defining issue is the goal of Scottish independence, and its supporters could easily understand this from any of their statements.

Using panel data from the BES, we find that voters who favour Scottish independence at the time of the independence referendum were generally more inclined to vote against Brexit; however, those who favour Scottish independence and identify with the SNP were more inclined to vote in favour of the UK leaving the EU. These findings are consistent with a story in which some pro-independence SNP supporters behaved as if they were voting tactically for a new Scottish referendum.

On a practical level, these results hold important implications for politics in Scotland, the UK and the EU. They suggest that the Scottish vote totals may have under-predicted support to remain in the EU. Further, although we only find evidence that a small percentage of SNP voters choose this route, these results suggest that we are better able to predict reported vote intentions for nearly two percent of the sample once accounting for the tactical voting argument. ${ }^{17}$ Projected to the UK level, this change in votes could have tipped the balance in support for remaining in the EU.

Our results also have implications for our understanding of voter behaviour in general and the role of party division in determining voter behaviour, more specifically. First, these results demonstrate that, when provided with uncertain long term incentives, some voters diverge from their short term preferences and vote instrumentally. As most Scottish voters maintain a preference and affinity for the EU, these results suggest that many Scots chose to vote in favour of Brexit, ignoring their preference to stay in the EU, with the hope of achieving their long-term goal of independence through a second Scottish referendum. This result adds further nuance to a theory of the relationship between

clarified the party's earlier position requiring that polls consistently show over $60 \%$ support for independence (The Scotsman, October 18, 2015).

${ }_{17}$ A model without the dummy variables for reported vote in the Scottish independence referendum and identifying with the SNP correctly predicts approximately $77.5 \%$ of the EU vote intentions, whereas our fully specified model improves the accuracy rate to $79.2 \%$. 
European integration and regional nationalism in Europe (e.g. Jolly 2015). Second, our results show that intra-party division plays a large role in influencing vote choice. While parties' campaign statements likely influence supporters' preferences, intra-party division limits the extent. Messages from the party leadership do not wholly determine supporters' votes. Furthermore, the salience of major issues, such as Scottish independence, to voters likely determines their willingness to deviate from the leadership's priorities. Ultimately, referendums can create the opportunity for tactical voting depending on the potential outcome of the proposed policy change. 


\section{BIBLIOGRAPHY}

Adams, James. 1999. "Policy divergence in multicandidate probabilistic spatial voting." Public Choice 100(1-2): 103-122.

Aldrich, John H. 1995. Why parties? The origin and transformation of political parties in America. Chicago: Chicago University Press.

Bäck, Hanna, Marc Debus, and Jochen Müller. 2014. "Who Takes the Parliamentary Floor? The Role of Gender in Speech-making in the Swedish Riksdag." Political Research Quarterly 67(3): 504-518.

BBC. 2015. “Election 2015: Sturgeon says only 'material change' could spark Scots referendum." April 8. http://www.bbc.co.uk/news/election-2015-scotland-32222806 (September 14, 2016).

Ceron, Andrea. 2012. "Bounded oligarchy: How and when factions constrain leaders in party position-taking." Electoral Studies 31(4): 689-701.

Ceron, Andrea. 2013. "Brave rebels stay home: Assessing the effect of intra-party ideological heterogeneity and party whip on roll-call votes." Party Politics 21(2): 246-258.

Ceron, Andrea. 2014. "Inter-factional conflicts and government formation Do party leaders sort out ideological heterogeneity?" Party Politics. DOI: 10.1177/1354068814563974.

Cox, Gary W. 1997. Making votes count: strategic coordination in the world's electoral systems. Cambridge University Press.

Curtice, John. 2016. "Indyref2 - Has the tide turned since the Brexit vote?" BBC, June 27. http://www.bbc.co.uk/news/uk-scotland-scotland-politics-36646789 (September 14, 2016).

Dalton, Russell J. and Martin P. Wattenberg. 2000. Parties without partisans: Political change in advanced industrial democracies. New York: Oxford University Press.

Dalton, Russell J., David M. Farrell, and Ian McAllister. 2011. Political parties and democratic linkage: How parties organize democracy. Oxford University Press.

Darcy, Robert. and Michael Laver. 1999. "Referendum dynamics and the Irish divorce amendment." Public Opinion Quarterly 54(1): 1-20.

Downs, Anthony. 1957. An economic theory of democracy. New York: Harper.

Fieldhouse, Edward, Jane Green, Geoffrey Evans, Hermann Schmitt, Cees van der Eijk, Jon Mellon and Chris Prosser. 2016. British Election Study Internet Panel Waves 1-10. DOI: 10.15127/1.293723 
Fortunato, David, and Randolph T. Stevenson. 2013. "Perceptions of partisan ideologies: The effect of coalition participation." American Journal of Political Science 57(2): 459-477.

Franklin, Mark N., Cees van der Eijk, and Michael Marsh. 1995. "Referendum outcomes and trust in government: Public support for Europe in the wake of Maastricht." West European Politics 18(3): 101-117.

Green, Christopher. 2016. "EU Referendum: Scottish Nationalists 'may vote to leave to speed up route to independence.'” The Independent (January 28).

Green, Jane, and Will Jennings. 2012a. "The dynamics of issue competence and vote for parties in and out of power: An analysis of valence in Britain, 1979-1997." European Journal of Political Research 51(4): 469-503.

Green, Jane, and Will Jennings. 2012b. "Valence as macro-competence: an analysis of mood in party competence evaluations in Great Britain." British Journal of Political Science 42(2): 311-343.

Greene, Zachary. 2015. "Competing on the issues How experience in government and economic conditions influence the scope of parties' policy messages." Party Politics. DOI: $10.1177 / 1354068814567026$.

Greene, Zachary, and Matthias Haber. 2015. "The consequences of appearing divided: An analysis of party evaluations and vote choice." Electoral Studies 37: 15-27.

Greene, Zachary, and Diana Z. O'Brien. 2016. “Diverse parties, diverse agendas? Female politicians and the parliamentary party's role in platform formation." European Journal of Political Research 55(3): 435-453.

Gschwend, Thomas. 2007. "Ticket-splitting and strategic voting under mixed electoral rules: Evidence from Germany." European Journal of Political Research 46(1): 1-23.

Hanley, Seán. 2004. "A Nation of Sceptics? The Czech EU Accession Referendum of 13-14 June 2003." West European Politics 27(4): 691-715.

Hobolt, Sara Binzer. 2005. "When Europe matters: The impact of political information on voting behaviour in EU referendums." Journal of Elections, Public Opinion and Parties 15(1): 85-109.

Johnson, Simon. 2016, May 27. “Alex Salmond 'should quit the Remain campaign before he does more damage.'” The Telegraph. Retrieved from http://www.telegraph.co.uk/.

Jolly, Seth. 2015. The European Union and the Rise of Regionalist Parties. Ann Arbor, MI: The University of Michigan Press. 
Jones, Richard Wyn, and Roger Scully. 2012. Wales Says Yes: Devolution and the 2011 Welsh Referendum. University of Wales Press.

Lago, Ignacio. 2008. "Rational expectations or heuristics?" Strategic voting in proportional representation systems." Party Politics 14(1): 31-49.

Lau, Richard R., and David P. Redlawsk. 2001. "Advantages and disadvantages of cognitive heuristics in political decision making." American Journal of Political Science 45(4): 951971.

Lawson, Kay. 1980. Political parties and linkage: A comparative perspective. New Haven: Yale University Press.

Levendusky, Matthew. 2010. "Clearer cues, more consistent voters: A benefit to elite polarization." Political Behavior 32(1): 111-131.

Long, Scott. 1997. Regression models for categorical and limited dependent variables. Sage Publications: Thousand Oaks, CA.

Lupia, Arthur. 1994. "Shortcuts versus encyclopedias: Information and voting behavior in California insurance reform elections." American Political Science Review 88(1): 63-76.

Lupia, Arthur, and Mathew McCubbins. 1998. The democratic dilemma: Can citizens learn what they need to know. Cambridge: Cambridge University Press.

Lupu, Noam. 2013. "Party brands and partisanship: Theory with evidence from a survey experiment in Argentina." American Journal of Political Science 57(1): 49-64.

Markowski, Radoslaw, and Joshua A. Tucker. 2005. "Pocketbooks, politics, and parties: the 2003 Polish referendum on EU membership." Electoral Studies 24(3): 409-433.

Marsh, Michael. 2015. "Voting on Europe, again and again: Stability and change in the Irish experience with EU referendums." Electoral Studies 38: 170-182.

Meffert, Michael F., and Thomas Gschwend. 2010. "Strategic coalition voting: Evidence from Austria." Electoral Studies 29(3): 339-349.

Mikkel, Evald, and Geoffrey Pridham. 2004. "Clinching the 'Return to Europe': The Referendums on EU Accession in Estonia and Latvia." West European Politics 27(4): 716-748.

Petrocik, John R. 1996. "Issue ownership in presidential elections, with a 1980 case study." American Journal of Political Science 40(3): 825-850. 
Pyeatt, Nicholas L. and Alixandra B. Yanus. 2016. "Sending mixed signals: The role of partisanship in evaluations of political leaders." Journal of Elections, Public Opinion and Parties 26(4): 423-434.

Quinlan, Stephen. 2012. “The Lisbon experience in Ireland: 'No' in 2008 but 'yes' in 2009 how and why?" Irish Political Studies 27(1): 139-153.

Schumacher, Gijs, Catherine E. de Vries, and Barbara Vis. 2013. "Why do parties change position? Party organization and environmental incentives." Journal of Politics 75(2): $464-477$.

Shepsle, Kenneth A. 1972. "The strategy of ambiguity: Uncertainty and electoral competition." American Political Science Review 66(2): 555-568.

Siune, Karen, Palle Svensson, and Ole Tonsgaard. 1994. "The European Union: The Danes 'no' in 1992 but 'Yes' in 1995 - how and why?' Electoral Studies 13(2): 107-116.

Somer-Topcu, Zeynep. 2015. "Everything to everyone: The electoral consequences of the broad-appeal strategy in Europe." American Journal of Political Science 59(4): 841-854.

Spoon, Jae-Jae. 2011. Political survival of small parties in Europe. Ann Arbor: University of Michigan Press.

Spoon, Jae-Jae and Heike Klüver. 2017. “Does anybody notice? How policy positions of coalition parties are perceived by voters." European Journal of Political Research. 56: 115-132.

Spoon, Jae-Jae, and Christopher J. Williams. 2017. "It takes two: How euroskeptic public opinion and party divisions influence party positions." West European Politics. 40(4): 741-762.

The Electoral Commission. 2016. "EU Referendum Results."

http://www.electoralcommission.org.uk/find-information-by-subject/elections-andreferendums/past-elections-and-referendums/eu-referendum/electorate-and-countinformation. (Accessed November 21, 2016).

The Scotsman. 2015. "SNP: 60\% support needed before next independence referendum." October 18. http://www.scotsman.com/news/politics/snp-60-support-needed-beforenext-independence-referendum-1-3920508 (September 14, 2016).

Uleri, Pier Vincenzo, and Michael Gallagher. 2016. The referendum experience in Europe. Springer.

Van der Brug, Wouter. 2004. "Issue ownership and party choice." Electoral Studies 23(2): 209233. 
Vegetti, Federico. 2014. "From political conflict to partisan evaluations: How citizens assess party ideology and competence in polarized elections." Electoral Studies 35: 230-241.

Vreese, Claes H. De, and Holli A. Semetko. 2004. "News matters: Influences on the vote in the Danish 2000 euro referendum campaign." European Journal of Political Research 43(5): 699-722.

de Vries, Catherine E., and Sara B. Hobolt. 2012. "When dimensions collide: The electoral success of issue entrepreneurs." European Union Politics 13(2): 246-268. 
TABLES AND FIGURES

Table 1. Vote Choice in the EU Referendum

\begin{tabular}{|c|c|c|c|}
\hline & Model 1 & Model 2 & Model 3 \\
\hline Ind. Ref. Vote & $\begin{array}{l}-0.266^{* *} \\
(0.114)\end{array}$ & $\begin{array}{l}-0.146 \\
(0.142)\end{array}$ & $\begin{array}{l}-0.359^{* *} \\
(0.157)\end{array}$ \\
\hline SNP Identification & . & $\begin{array}{l}-0.20 \\
(0.155)\end{array}$ & $\begin{array}{l}-1.610 \\
(0.451)\end{array}$ \\
\hline $\begin{array}{l}\text { Ind. Ref. Vote* } \\
\text { SNP Identification }\end{array}$ & . & . & $\begin{array}{l}1.657^{* * *} \\
(0.481)\end{array}$ \\
\hline Age Group & $\begin{array}{l}0.148^{* * *} \\
(0.042)\end{array}$ & $\begin{array}{l}0.153^{* * *} \\
(0.042)\end{array}$ & $\begin{array}{l}0.155^{* * *} \\
(0.042)\end{array}$ \\
\hline Education & $\begin{array}{l}-0.066^{* * *} \\
(0.012)\end{array}$ & $\begin{array}{l}-0.067^{* * * *} \\
(0.012)\end{array}$ & $\begin{array}{l}-0.070^{* * * *} \\
(0.012)\end{array}$ \\
\hline Gender & $\begin{array}{l}0.038 \\
(0.126)\end{array}$ & $\begin{array}{l}0.035 \\
(0.126)\end{array}$ & $\begin{array}{l}0.039 \\
(0.126)\end{array}$ \\
\hline Marital Status & $\begin{array}{l}-0.039 \\
(0.122)\end{array}$ & $\begin{array}{l}-0.044 \\
(0.123)\end{array}$ & $\begin{array}{l}-0.053 \\
(0.123)\end{array}$ \\
\hline Personal Income & $\begin{array}{l}-0.032 \\
(0.022)\end{array}$ & $\begin{array}{l}-0.032 \\
(0.022)\end{array}$ & $\begin{array}{l}-0.032 \\
(0.022)\end{array}$ \\
\hline EU Efficacy & $\begin{array}{l}0.123^{*} \\
(0.070)\end{array}$ & $\begin{array}{l}0.124^{*} \\
(0.070)\end{array}$ & $\begin{array}{l}0.111 \\
(0.071)\end{array}$ \\
\hline EU Political Knowledge & $\begin{array}{l}-0.003 \\
(0.015)\end{array}$ & $\begin{array}{l}-0.003 \\
(0.015)\end{array}$ & $\begin{array}{l}-0.003 \\
(0.015)\end{array}$ \\
\hline Campaign Info. Scale & $\begin{array}{l}5.985^{* * *} \\
(0.522)\end{array}$ & $\begin{array}{l}5.987^{* * *} \\
(0.522)\end{array}$ & $\begin{array}{l}6.003^{* * *} \\
(0.523)\end{array}$ \\
\hline Constant & $\begin{array}{l}-0.710 \\
(0.451)\end{array}$ & $\begin{array}{l}-0.700 \\
(0.450)\end{array}$ & $\begin{array}{l}-0.585 \\
(0.588)\end{array}$ \\
\hline AIC & 1810.984 & 1811.445 & 1800.863 \\
\hline $\mathrm{BIC}$ & 1866.771 & 1872.810 & 1867.807 \\
\hline$X^{2}$ & 198.280 & 201.550 & 202.540 \\
\hline Log-Likelihood & -895.492 & -894.722 & -888.431 \\
\hline $\begin{array}{l}\text { Percent Correctly } \\
\text { Predicted }\end{array}$ & .789 & .791 & .792 \\
\hline Observations & 1956 & 1956 & 1956 \\
\hline
\end{tabular}

Notes: ${ }^{* * *} p<0.01,{ }^{* *} p<0.05,{ }^{*} p<0.10$. We present the results of logistic regression models in Table 1 predicting the likelihood that a respondent reports voting for Brexit with Huber-White robust standard errors in parentheses. 
Figure 1. Likelihood of Voting In Favour of Brexit for Full Sample (Model 1) ${ }^{18}$

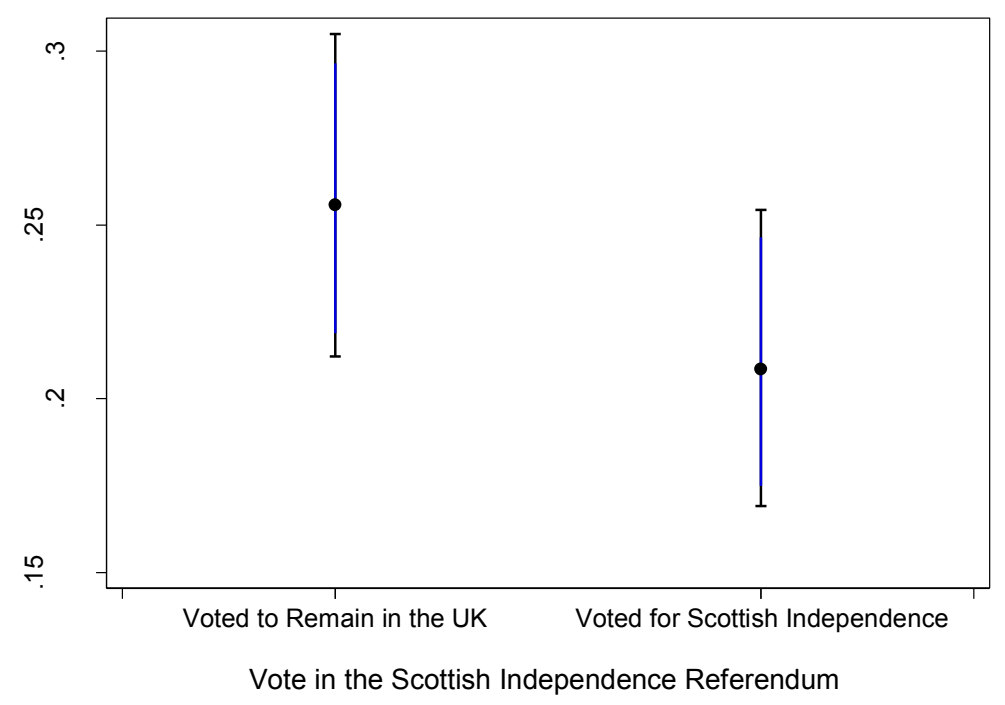

Figure 2. Likelihood of Voting In Favour of Brexit for SNP Identifiers (Model 3)

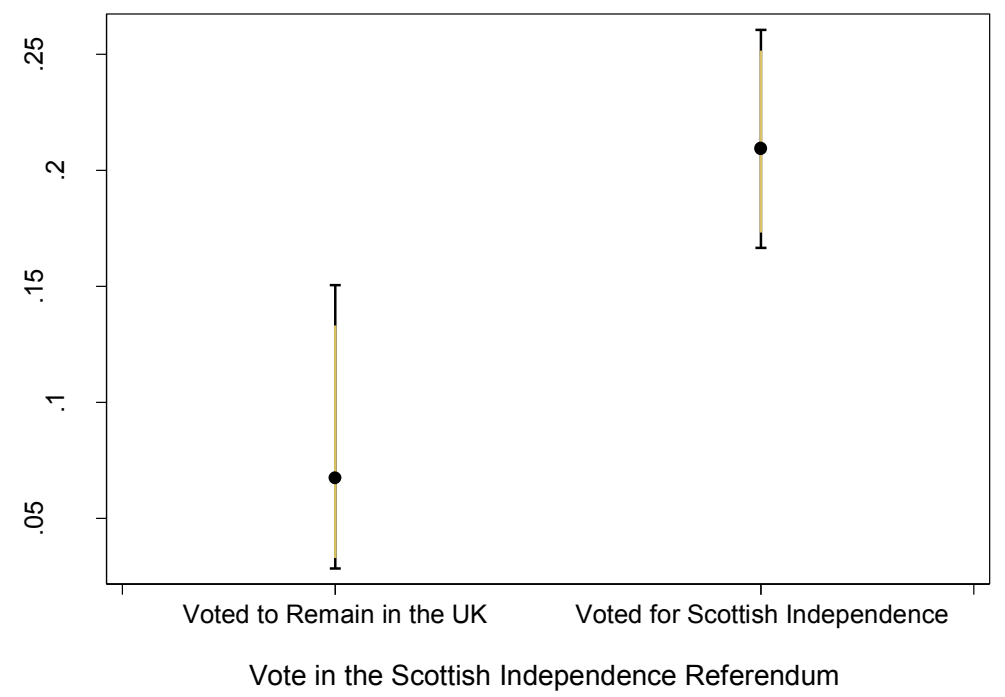

18 Predicted likelihoods in Figure 1 and Figure 2 are estimated from 1000 draws of the variancecovariance matrix based on the results presented in Model 1 and 3, respectively. Independent variables are held at their mean values for continuous variables and at the median values for dichotomous variables. The predicted probabilities are the median predicted value with $90 \%$ (lighter lines) and 95\% (darker lines) confidence intervals. 